\title{
GEOGRAFIA NO ESPAÇO VIRTUAL E PANDEMIA: PROCESSOS INCLUSIVOS E EXCLUDENTES NA FORMAÇÃO DE PROFESSORES NO TOCANTINS
}

\author{
Antônia Márcia Duarte Queiroz \\ Doutora em Geografia pela Universidade Federal de Uberlândia (UFU) \\ Professora Adjunta na Universidade Federal do Tocantins-UFT \\ amdq@uft.edu.br
}

\begin{abstract}
RESUMO
O objetivo desse trabalho foi identificar as iniciativas da educação ofertadas pelo curso de Geografia e as atividades oferecidas pela universidade Federal do Tocantins - UFT, durante o período de pandemia Covi-19 no Brasil. Em específico, entendermos a situação dos estudantes, a estrutura de funcionamento desse curso e a Universidade na formação de professores, a luz das discussões e a utilização do Ensino Híbrido e Ensino Remoto, em virtude do isolamento social em todo o país. A metodologia qualitativa partiu de análise teórica, de resultados de questionário e das ações de ensino, pesquisa e extensão on-line, realizadas pelo curso de Geografia e pela universidade, disponíveis na página oficial da UFT. Assim, foram levantadas reflexões a partir da articulação do curso de Geografia, com a instituição e a interlocução professor/estudante no espaço virtual. A especificidade desse confronto nos mostrou formas de inclusão e exclusão pelas TICs, de diversas maneiras, tais como social, afetiva e de conhecimento. Por um lado, na formação de professores, nesse contexto regional, a modalidade de educação on-line, privilegia poucos estudantes, aqueles que possuem acesso as redes das TICs. Por outro lado, exclui muitos estudantes que não possuem acesso aos instrumentos midiáticos nesse momento de pandemia e, até mesmo durante toda a sua formação acadêmica.
\end{abstract}

Palavras-chave: Pandemia. TICs. Educação. Ensino geográfico.

\section{GEOGRAPHY IN THE VIRTUAL SPACE AND PANDEMIC: INCLUSIVE AND EXCLUSIONARY PROCESSES IN TEACHER EDUCATION IN BRAZIL}

\begin{abstract}
The objective of this work was to identify the education initiatives offered by the Geography course and the activities offered by the Universidade Federal do Tocantins - UFT, during the pandemic period. In particular, we understand the situation of students, the structure of the geography course and the University in teacher training, the light of discussions and the use of Ensino Remoto due to social isolation throughout the country. The qualitative methodology started from theoretical analysis, results of online questionnaire and actions carried out by the Geography course and the university, available in the course and on the official website of the UFT. Thus, reflections were raised from the articulation of the course with the institution and the teacher/student dialogue in the virtual space. The specificity of this confrontation showed us forms of inclusion and exclusion by ICT, in various ways, such as social, affective and knowledge. On the one hand, the modality of online education privileges to a few students in the initial education, those who have access to ICT networks and, on the other hand, excludes many students who do not have access to media instruments, during the pandemic and even during their entire training in the Brazilian regional context.
\end{abstract}

Keywords: Pandemic. ICT. Education. Geographic teaching.

\section{INTRODUÇÃO}

O acesso às TICs faz parte de processos excludentes de grande parte da população brasileira, e por outro lado há iniciativas de políticas públicas de inserção às TICs, por meio das instituições públicas de educação no Brasil. Essa dicotomia se apresenta pelos números de domicílios com acesso à internet 
e pelas possibilidades de os estudantes se inserirem nos espaços virtuais de ensino regionais, como também estarem conectados às nuances globais da sociedade digital como um todo.

A finalidade é entendermos a situação dos estudantes, a estrutura de funcionamento do curso de Geografia e da Universidade Federal do Tocantins durante a Pandemia Covid-19, em meio as discussões do Ensino Híbrido e Ensino Remoto no Brasil.

Na perspectiva de Valente (2014) as Tecnologias Digitais de Informação e Comunicação -TDICs, direcionadas ao ensino é conhecido como blended learning ou Ensino Híbrido, que combina atividades presenciais e atividades educacionais a distância, as quais na atualidade se configura na educação brasileira.

A Universidade Federal do Tocantins já fazia uso do Ensino Híbrido, conforme previsto na Portaria no 4.059, de 10 de dezembro de 2004, do Ministério da Educação de até 20\% (vinte por cento) da carga horária total do curso, utilizando a modalidade semipresencial para oferta das disciplinas ou atividades integrantes e complementares do currículo dos cursos.

Em meio a Pandemia, o Ensino Remoto Emergencial foi implementado pelas universidades públicas federais brasileiras, a qual transpôs o ensino presencial físico para os meios digitais, por meio de aula síncrona, por meio de videoaula, aula expositiva por sistema de webconferência, e as atividades assíncronas seguem durante a semana no espaço de um ambiente virtual de aprendizagem (AVA). Dessa maneira, a Universidade Federal do Tocantins, obrigatoriamente se inseriu nesse contexto.

Nesse sentido, o objetivo desse trabalho é analisar as iniciativas de educação no Ensino Remoto emergencial na Universidade Federal do Tocantins -UFT, por intermédio das atividades realizadas pelo curso de Geografia/Campus Araguaína.

A metodologia utilizada seguiu por meio de análise teórica, de resultados de questionário e das ações realizadas pelo curso de Geografia e da universidade na modalidade de ensino on-line, disponíveis no site oficial da UFT. A análise qualitativa permitiu coletarmos informações e verificarmos como o ensino de Geografia está se adaptando as estratégias do Ensino Remoto. De mais a mais foram levantadas reflexões a partir da articulação desse curso na instituição e a interlocução entre professor e estudante do curso no espaço virtual. Essa investigação trouxe linhas de confrontações dos dados encontrados, sobre a Geografia, com as peculiaridades das tecnologias de informação e comunicação e o conhecimento do contexto regional.

A especificidade desse confronto nos mostrou formas de inclusão e exclusão pelas TICs de diversas maneiras, social, afetiva e de conhecimento. Por um lado, privilegia a poucos estudantes na formação inicial, aqueles que possuem acesso as redes das TICs. E, por outro lado exclui muitos estudantes que não possuem acesso aos instrumentos midiáticos e internet, durante esse período de pandemia e até mesmo durante toda a sua formação no ensino superior.

Ademais, buscamos analisar as experiências na universidade, mostrando como o ensino no espaço virtual se apresenta para os estudantes no norte do Tocantins. Além disso, almejamos evidenciar os alcances e as limitações do Ensino Remoto, em especial na modalidade a distância on-line, frente aos desafios dessas relações no contexto regional, a articulação docente e discente e, sobretudo, buscando novas reflexões sobre a formação docente direcionada à articulação da informação e comunicação no espaço virtual de ensino e aprendizagem.

O artigo está dividido em três partes, mais as considerações finais. A primeira abordagem desenvolve discussões conceituais sobre exclusão e inclusão, para posteriormente entendermos esses termos a partir das nuances das TICs. A segunda parte, com base em levantamento bibliográfico discute-se sobre o acesso às TICs e à internet no Brasil, em particular trata acerca dessa problemática da educação no espaço virtual, no país, em tempos de pandemia. A terceira parte reflete sobre os desafios para a formação de professores de Geografia no espaço virtual no Norte do tocantins. Essa análise se 
direciona às perspectivas e possibilidades de acesso às TICs, a apropriação e uso da educação online por estudantes durante o período de pandemia. Em especial, o aproveitamento dos instrumentos digitais, mais acessíveis aos estudantes e disponíveis ao ensino-aprendizagem, para o ensino superior e espaço escolar, presentes no contexto regional no Norte do Tocantins.

\title{
ARTICULAÇÕES TEÓRICAS PARA COMPREENSÃO DOS TERMOS EXCLUSÃO E INCLUSÃO PELAS TICS NO BRASIL
}

Para Martins (1997) não existe exclusão, o que chamam de exclusão é aquilo que constitui o conjunto das dificuldades, dos modos e dos problemas de uma inclusão precária e instável, marginal. A inclusão seria daqueles que estão sendo alcançados pela nova desigualdade social produzida pelas grandes transformações econômicas e, para os quais, não há senão, na sociedade, lugares residuais. Assim, considera uma forma imperfeita, insuficiente e equivocada para expressar um conceito que não consegue explicar o termo exclusão, a qual permite interpretações variadas e complexas, as quais se sobrepõem ao termo "pobre", utilizado a priori na sociedade capitalista.

Martins (1997) acredita que é um fenômeno geral que acontece de modos diferentes, em toda sociedade. Refere-se aos processos resultantes das relações sociais.

\section{[...] a palavra exclusão indica uma dificuldade, mais que uma certeza - revela uma incerteza no conhecimento que se pode ter a respeito daquilo que constitui o objeto da nossa preocupação- a preocupação com os pobres, os marginalizados, os excluídos, os que estão procurando identidade e um lugar aceitável na sociedade. Portanto, a palavra exclusão nos fala, possivelmente, de um lado, da necessidade prática de uma compreensão nova daquilo que, não faz muito, todos chamávamos de pobreza. (MARTINS, 1997, p.28)}

Nessa abordagem, exclusão é vista como um processo acumulativo de constantes rupturas que envolvem pertencimento ou não pertencimento de pessoas, grupos, comunidades e territórios nas relações econômicas, políticas e culturais. Estas permitem fluxos diversos de papéis, sejam semelhantes ou dicotômicos, de ação e conduta, que, ao se separarem, promovem a exclusão a partir da falta de interação e articulação de troca social.

Castel (1998) afirma que a questão social surge em 1830, a partir da tomada de consciência das condições das populações vítimas da Revolução Industrial. Havia formas institucionalizadas de relações não mercantis referentes a distintas classes de indigentes (as práticas e instituições de assistência) e havia o social- assistencial.

As políticas de inserção podem ser compreendidas como um conjunto de empreendimentos de reequilíbrio para recuperar a distância em relação a uma completa integração. "[...] Um quadro de vida decente, uma escolaridade normal, um emprego estável” (CASTEL,1998, p. 538). Apesar do impulso do estado nas causas sociais, diante do fracasso do mesmo em oferecer condições de resguardar as necessidades mínimas de sobrevivência da maioria da população, o crescimento de mobilizações populares se torna necessário e busca alternativas usando de novas ideologias para a sociedade, capazes de viabilizar melhores condições sociais.

No início dos anos 1980, surgem as primeiras políticas de inserção com medidas econômicas e políticas, oriundas do pensamento socialista, em busca de certezas e intervenção mediante as necessidades das populações no quadro social e político do período.

\begin{abstract}
[...] o contrato de inserção é a contrapartida da atribuição de recursos que ligam o beneficiário à realização de um projeto, mas que compromete igualmente a comunidade nacional que deveria ajudá-lo a realizar esse projeto. Tentativa de quebrar a imagem secular do" mau pobre", que vive como parasita quando deveria trabalhar, mas também de fazer desaparecer o estigma do assistido, beneficiário passivo de um socorro que é a contrapartida de sua impotência para se assumir a si próprio [...] (CASTEL,1998, p.553).
\end{abstract}

Acredita-se que inserção social é propiciar oportunidades e inserir condições sociais abrangentes nas áreas de educação, saúde e trabalho nas comunidades que se encontram desprovidas de condições básicas para sobrevivência, os excluídos da sociedade. Mais do que isso, a inserção social depende de instrumentos que integrem as habilidades humanas às transformações político-sociais regionais, municipais, estaduais e federais, as quais são responsáveis em conduzir e influenciar suportes adaptados às necessidades de cada uma destas esferas com alternativas viáveis, que possibilitem um

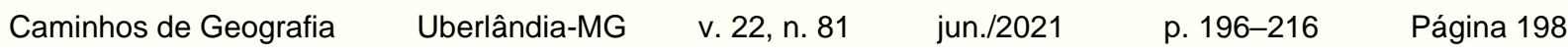


novo modo de agir nas comunidades mais carentes, eficazes na promoção de desenvolvimento coletivo.

De modo geral, as afirmações supracitadas podem significar que, para o sujeito não ser considerado excluído na sociedade, ele necessita da inserção oriunda de todos os meios de produção social, econômica, política, de saúde, educação e, principlamente, de trabalho. Então, faz se necessário compreender como se dá esse processo no cenário brasileiro para entender medidas de inclusão digital na educação.

No Brasil, Martins (1997) enfatiza o papel do capitalismo que reproduz contradições sociais e dicotomias, as quais, no Brasil, foram vistas como saída para a modernização da sociedade e alternativas de emprego, trabalho e de inserção no mercado. Posteriormente, esse posicionamento se mostrou utópica porque as tentativas de modernização propostas, naquele período pela igreja e pelo governo militar no Brasil, considerado um país de capitalismo atrasado, lançaram-se em uma política de modernização excludente, que resulta no fortalecimento do poder econômico e político entre os donos do capital e proprietários de terras brasileiras. Promoveram a aliança entre estado e as oligarquias, o que revelou uma burguesia conservadora e mantenedora do acirramento da pobreza e marginalização política e social da maioria da população.

O autor revela que, no Brasil, a condição de exclusão torna-se visível a partir dos camponeses expulsos da terra, uma população sem condições de se inserir nos padrões de desenvolvimento econômico que se configura na atualidade e não consegue sobreviver. São reabsorvidos como escravos, para trabalhar em troca de comida. É uma forma de inclusão que se perpetua.

A exclusão só é percebida quando há expulsão do trabalhador de um setor e ele não consegue se integrar a outro. Isso permite alteração de uma ordem que é estabelecida na sociedade e sobrevém uma categoria que se fixa à margem. É latente no Brasil essa massa de população que se apresenta carente de conhecimento, cultura e especialização, desprovida de instrumentos de ação e reação.

Martins (1997) acredita que, quando ocorre a reprodução ampliada do capital, ocorre também a reprodução ampliada das contradições sociais. A tendência à aparente perpetuação do capitalismo, de sua exploração e de suas relações de poder não se repete sem reproduzir consigo aquilo que a nega e que propõe, no próprio bojo da exploração e da opressão, a libertação.

O poder absoluto do capitalismo não existe, é uma farsa e uma fraude, é um sonho de capitalistas. O problema da exclusão nasce com a sociedade capitalista europeia, a qual tem uma lógica de desenraizar e excluir regida pelas leis do mercado, o movimento e a circulação. No Brasil, o Estado vem se orientando em suas políticas econômicas por propostas de modernização econômica divorciada da modernização (e re-inclusão) social.

Nesse sentido, o contexto do avanço capitalista no Brasil se diferencia da história europeia. Apresenta uma elite fragmentada entre os interesses agrários e os interesses capitalistas e se firma a partir de interesses articulados agrário-capitalista, os quais controlam ainda hoje o aparelho do Estado, mediante acordos políticos firmados no poder das elites fundiárias. "Estamos em face de um estado parasitado por um sistema de poder que se baseia em privilégios, e não em direitos" (MARTINS, 1997, p. 93).

Suas análises sintetizam que os interesses de poder econômico no Brasil existem por meio de um estado controlado, por um tipo de conveniência que se articula pelo poder político e econômico. Perpetua-se alicerçada em bases firmadas a partir da herança fundiária, monopolista e escravista, que se configuram no limiar da história brasileira na concepção de Estado oligárquico. Para Martins (1997, p.137), o capitalismo em si não é um bem, não resolve o problema da exclusão. "Não resolve o problema da supressão da decência na vida das pessoas. Que o capitalismo pode ser e, frequentemente é, sobretudo nos países pobres, mais do que amoral, imoral".

Florestan Fernandes (1975) afirma a importância de uma efetiva Revolução Burguesa que ocorreu em diversos países, a qual significa transformações econômicas, políticas, tecnológicas, sociais e psicoculturais, que se desenvolvem quando o capitalismo atinge o ápice de sua evolução industrial. Diante disso, evidencia-se no Brasil a inviabilização de uma efetiva Revolução Burguesa.

O autor considera que houve no fim do Império e começo da República uma reestruturação, a qual manteve a oligarquia no poder, uma transição de poder burguês e dominação burguesa em um contexto histórico da Abolição da Escravatura, Proclamação da República e inquietações da década de 1920. O argumento vislumbra reafirmações oligárquicas e a formação de uma burguesia diferenciada no contexto brasileiro, a qual mantém o controle das estruturas políticas, sociais, econômicas e de poder. 
Essa situação foi responsável por eclosões de conflitos, amplamente reprimidos, e um modelo burguês dedicado à modernização em âmbito empresarial e de crescimento econômico, evolução do capitalismo competitivo por meio da exportação e importação sem romper com as condições de dependência outrora estabelecidas.

O Estado agia de acordo com interesses do capital monopolista, que se destaca apresentando um aparente desenvolvimento de renda, melhor padrão de vida e infraestrutura para atender interesses capitalistas de empresas particulares. Assim, permaneciam-se as bases consolidadas do escravismo ao lado do desenvolvimento modernizador industrial/ urbano.

Tal análise se reporta à reflexão de aspectos sociais, políticos e econômicos por meio das implicações capitalistas e da figura interventora do estado. Castel (1998) trata o estado social como fiador e responsável por assumir a solidariedade quando as delegações da sociedade econômica estão abaladas. Redefinem-se por meio de pacto de solidariedade, trabalho e cidadania com formas de pensar a inclusão de todos no edificar a coesão social.

Seu diagnóstico se apoia na condição de assalariado que se estabiliza e determina que o estado deva possuir sistemas de socorro público, cobrar impostos, recrutar pessoal, criar instituições especiais, já o trabalho atende uma classe privilegiada e vulneraliza, ainda mais, grande quantidade de indivíduos. Vislumbra um estado social com poder de proteção atuante entre a dinâmica econômica e a preocupação exigida pela solidariedade.

Essas proposições emergem do surgimento de populações marginais desde os tempos remotos e se acentuam depois da industrialização. A posição do estado na intervenção social ora é restringida, ora é totalmente dirigida a partir da intervenção estatal na economia, política e social por meio da produtividade, das categorias que se beneficiam sempre em movimento, em sentido de assegurar um mínimo de coesão entre os grupos sociais. Nesse sentido, (MATOS, 2005, p. 24) considera que no Brasil:

Mudanças importantes vinham-se acumulando desde os anos de 1950, abrangendo a urbanização, o crescimento demográfico, as migrações de tipo campo-cidade, a industrialização, o mercado de trabalho, o padrão de crescimento econômico e a maior inserção do país na economia mundial. [...] Diante dessa reconfiguração, persistem as dicotomias "moderno X atrasado", "dinâmico X estagnado [...]"?

As pesquisas de Matos (2005) revelam ideias sobre a economia mundial, enfatizam aspectos econômicos, políticos e culturais a partir das indagações do local e do global, demonstram a preocupação com problemas inerentes à pobreza que se alastra no mundo, fruto da reestruturação econômica atual. As formas de debates discutidas mundialmente giram em torno do combate à pobreza por meio do fortalecimento das instâncias de poderes locais, sustentabilidade ambiental, expansão do emprego e inclusão, gestão participativa e co-gestão, parcerias público-privadas, ações afirmativas e cooperação interinstitucional envolvendo entidades governamentais e não-governamentais.

As características que configuram o Brasil no limiar histórico mostram uma situação de mudanças, sem alterar as estruturas do poder vigente. Essa situação viabiliza novas abordagens e ideias em busca de conceitos que expliquem termos excludentes nos processos de transição econômica e de modernização.

É visível uma realidade social assentada em diferentes sistemas de relações humanas, as quais estabelecem contato de diferentes tipos de desigualdades. As coletividades estão submetidas a sistemas locais e regionais de controle das formas de poder político e econômico. Partindo da consciência do desequilíbrio na noção de igualdades individuais e coletivas, surgem agentes modificadores da vida social, que buscam uma melhor qualificação humana.

Diante da constatação de novos paradigmas na construção social que se mobilizava em todo o mundo e das mudanças populares na busca de condições melhores de sobrevivência e participação, o Brasil tenta vincular direitos sociais coletivos mais concretos, que até então foram negados à maioria da população.

Neste sentido, a inserção social é o espaço que promove transformação social onde deve-se considerar a ação de sujeitos políticos e da sociedade com perspectivas coletivas contra a desigualdade. A década de 1990 se caracteriza pelo esforço de preservar e validar nos aspectos econômico-sociais oportunidades que permitam inclusão pelo acesso e integração nas diferentes capacidades individuais e coletivas consideradas marginalizadas.

Caminhos de Geografia Uberlândia-MG

$\begin{array}{lll}\text { v. } 22, \text { n. } 81 & \text { jun./2021 } 196-216\end{array}$

Página 200 
Existe, hoje, a preocupação com a inserção social, pois na sociedade surgem formas de conscientização por órgãos de representação social e solidária que vislumbram mudanças efetivas na busca de ações de qualidade, que atendam às questões sociais e desenvolvam projetos que possibilitem diminuir as diferenças, bem como promover o desenvolvimento em comunidades carentes, nos níveis de capacitar a inserção ao trabalho e garantir melhoria na educação.

Os argumentos trazem a compreensão de que existem várias formas de exclusão e de inserção. No entanto, é visível, em todas essas abordagens, a intervenção do Estado, que, de diversas maneiras, atua nesse processo, seja para coibir a exclusão e promover a inserção, ou ao contrário, coibir a inserção e promover, ainda mais, a exclusão de grande parcela da população dos processos capitalistas de produção, trabalho, saúde e educação.

$\mathrm{Na}$ atualidade, esses processos excludentes se desenvolvem, em grande parte, por meio da globalização das TICs, que trazem modificações significativas nas condições de produção capitalista e modos de vida da população, de modo geral, como trabalho, saúde e educação. Essas modificações necessitam de reflexões que tragam luz à compreensão desses fenômenos e às possibilidades de acesso a esses instrumentos.

\section{ESPAÇO VIRTUAL, EDUCAÇÃO E ENSINO GEOGRÁFICO}

Ressaltamos que utilizamos o termo espaço virtual de acordo com o nosso tema de tese de doutorado (Queiroz, 2016), discutido amplamente e embasada teoricamente na definição de Ferreira (2006) sobre Espaço eletrônico, definido pelas tecnologias de informação que influenciam as interações e a produtividade, representadas por computadores, redes de telecomunicações, mídia eletrônica e Internet.

Essa opção conceitual se desenvolve a partir das abordagens geográficas sobre o Espaço realizadas por Massey (2009) de que não pode existir separação entre o mundo do espaço físico e o mundo das conexões eletronicamente mediadas, pois a informação só tem utilidade em relação à localidade que habita. O espaço virtual depende do mundo material, dos pontos de acesso e da materialidade dos cabos. Ou seja, o mundo virtual depende do espaço físico.

Como não admitir que as relações humanas ocorram independentes do contato material? Se ao contato entre os professores a distância com os estudantes puder acontecer à percepção, troca de experiência, da imaginação e dos sentidos, então podemos afirmar que espaço virtual é um lugar imaterial abundante de mensagens e códigos, onde as pessoas e objetos técnicos se conectam e potencializam a construção de conhecimentos.

Portanto, pode significar um espaço de aprendizagem, pois os sujeitos trocam significados culturais, podem debater opiniões, ideias e diferenças e construir novos saberes e, assim, surgir o conhecimento.

Para Pierre Lévy (1996), o virtual é um espaço real e nossa própria experiência do cotidiano no uso destas ferramentas comprova isso.

Kerckhove (1997) contribui com o argumento ao afirmar que a realidade virtual é uma realidade que se pode sentir, ouvir e ver através dos sentidos reais, não só com ouvidos ou olhos imaginários. Penetrando na tela com a luva virtual, a mão real transforma-se numa metáfora técnica, tornando tangíveis as coisas que anteriormente eram apenas visíveis. A partir de agora, podemos querer tocar os conteúdos do pensamento. As mudanças numa página escrita ou numa tela pintada levam pelo menos alguns minutos. Agora a velocidade de interação atingiu a imediaticidade. Kerckhove (1997) assevera:

Esta conversa tecnológica quase cifrada leva a uma conclusão: com a manipulação de objetos em 3D em tempo real, o pensamento e o processamento estão a tornar-se a mesma coisa. Se por analogia o que acima foi dito para a educação de uma criança, estaremos a romper a barreira do ambiente escrito (KERCKHOVE, 1997, p.81).

Para Kerckhove (1997), o futuro pode ser encarado pela resolução de problemas como uma extensão em realidade virtual, pela tentativa de encontrar uma solução para um problema. A realidade virtual será melhorada com a simulação da totalidade do ambiente do processo de raciocínio gerada pelo pensamento combinado de várias pessoas que estão a pensar sobre o mesmo objeto. Talvez sejamos capazes de criar novos objetos apenas através do pensamento de forma colaborante, via digitalização, todas as fontes de informação, incluindo fenômenos materiais e processos naturais, incluindo as nossas sensações sensoriais. 
Kerckhove (2007) acrescenta que sistemas de realidade virtual, por exemplo, estão homogeneizados em cadeias sequenciais. A realidade virtual permitirá eventualmente as pessoas a encontrarem-se e trabalharem juntas em estações virtuais que já têm o nome de espaço comum virtual. A realidade virtual permite-nos entrar fisicamente nos produtos da nossa imaginação.

A imaginação científica geográfica se faz presente e traz características coerentes que permitem a afirmação do espaço virtual, consoante com as realidades apresentadas pela modalidade de educação na plataforma on-line. Contribuem para a afirmação da realidade construída nessas redes as pessoas que se encontram e se relacionam em atividades coletivas colaborativas, ou individuais reais e fisicamente articuladas pelas sensações, digitalização e acesso às fontes de informação. Consequentemente torna o invisível uma realidade imediatizada pela comunicação que emerge na rede das redes, ou seja, a internet.

Segundo Kerckhove (2007), à medida que penetramos nas realidades virtuais, estamos a entrar numa terceira era mediática, a cibercultura, que é o produto da multiplicação da massa pela velocidade com as tecnologias, com a mensagem e a imagem atreladas a redes neurais em sistemas operativos enormemente complexos e educáveis. Estamos a descobrir que há tanto lugar no espaço interior como no espaço exterior, e o homem da massa foi homogeneizado e bastante despersonalizado, a princípio preso no mundo da difusão mediática da televisão pela indústria da consciência e, hoje, pela velocidade dos computadores, está em todo o lado, no centro das coisas.

No mundo da velocidade, os homens não se movem, estão com acesso instantâneo às coisas e à informação, não são mais apenas consumidores, são também produtores e agentes em caráter pessoal. "A democratização e proliferação das comunicações instantâneas e dos aparelhos de telecomunicação pessoais substituíram nossa outrora opaca e distante percepção do planeta por uma nova percepção da sua imediatez e transparência" (KERCKHOVE, 2007, P. 190).

Para Kerckhove (2007), a diminuição do hiato entre ação e reação está a criar uma espécie de continuidade entre planejar e executar em tempo real.

O paradoxo é este o nosso hardware- a realidade material da terra- está a contrair-se e a implodir sobre si mesma, porque as nossas tecnologias reduzem constantemente os intervalos espaço-temporal entre operações. Entretanto, o nosso software- a nossa realidade psicológica e tecnológica, está continuamente a expandir-se. O acesso aos reinos do infinito - estruturas de informação atômicas e subatômicas, planetárias e galácticas - está também a expandir o alcance da nossa cultura em profundidade que não cessa de aumentar. (KERCKHOVE, 2007, P. 192).

O espaço virtual se constrói sob contextos dialéticos e paradoxais espaço/ temporais via cibercultura, que significa - ver através- para além da superfície visível, da matéria, do espaço e do tempo por meio das técnicas de recolha de informação das redes.

Kerckhove (2007) assevera que a liberdade pós-moderna expressa uma necessidade humana de recuperar a escala num ambiente crescentemente tecnológico, pois o modernismo surgiu de um mundo em que as pessoas não se sentem ameaçadas pela tecnologia. A memória coletiva tecnológica fornece os meios para uma exploração interminável em vários níveis de tempo acelerado pelo computador visto que o passado se integra num imenso presente prolongado.

O espaço que até o século $X X$ era considerado um vazio para as atividades do homem, hoje está invadido por redes de comunicação eletrônicas e está ainda mais vivo, pois as tecnologias invadem a realidade com pouca ou nenhuma resistência. "As tecnologias são tão versáteis que nos dão poder para refazer aquilo a que chamamos realidade. Com as tecnologias que manipulam o tempo, o espaço e o ser, o equilíbrio desfez-se" (KERCKHOVE, 2007, p.236).

Para o autor supracitado, na eminência da realidade virtual, podemos achar cada vez mais difícil distinguir entre as nossas identidades naturais e as extensões eletrônicas, com poder de estar em todo lado sem sairmos do mesmo local. A maneira instantânea globalizante de feedback elimina a adaptação e propõe o poder de dominação do mundo baseado no pensamento, o sentimento e a expressão da cultura tecnológica. No entanto, não temos um modelo que represente nossa presença no meio dessas imagens múltiplas das redes tecnológicas.

O espaço virtual pode estar repleto de contradições, que podem ir além dos fatos, ou fenômenos espaço- temporais para as relações humanas materiais e imateriais físicas ou psicológicas desenvolvidas pela ação e reação, pela informação e comunicação nas redes. 
De fato, na educação a distância-on-line, há articulações em diversos níveis de informação e comunicação entre os sujeitos pelas redes das TICs, que se movimentam viabilizadas pela globalização econômica, social e política.

As relações humanas por meio das TICs podem promover inserção de camada expressiva da população brasileira, mas pode também promover a exclusão da maioria da população. Essas condições para inserção ou exclusão podem ser dispostas em duas vertentes, uma de inserção que possibilita a facilidade à informação, comunicação pela acessibilidade ao conforto do computador e internet, das redes ligadas a diversas agências bancárias, comodidade que evita filas e facilita movimentações financeiras; compras por meio de sites nacionais e internacionais; ensino a distância, que dispensa o translado, problemas com trânsito e material didático, dentre outras. Já a outra vertente é a que exclui uma expressiva camada da sociedade que não dispõe dessas tecnologias e não pode usufruir dessas facilidades.

Os estudos em andamento nos permitem avançar mais uma hipótese: as qualidades de instantaneidade e de simultaneidade das redes de informação emergiram mediante a produção de novas complexidades no processo histórico. [...] que redesenharam o mapa do mundo, dos países e das regiões. Processos de múltiplas ordens: de integração produtiva, de integração de mercados, de integração financeira, de integração da informação. Mas processos igualmente de desintegração, de exclusão de vastas superfícies do globo (DIAS, 2001, p.146).

As novas configurações no significado de rede e das TICs remetem à inclusão de países na economia global, as quais são responsáveis por atuarem em vários modelos de exclusão social, pois a maioria da população mundial não participa dos benefícios oriundos da dinâmica dos grandes movimentos de capital, facilitados pela rede econômica mundial. A articulação de centros de grandes decisões centralizando e descentralizando processos econômicos de empresas e de organizações produtivas possibilita erros e impactos, de tendência de significado social e econômico, propiciado pela rede flexível oferecida pelo novo desenvolvimento tecnológico.

É de fato uma cultura, mas uma cultura do efêmero, uma cultura de cada decisão estratégica, uma colcha de retalhos de experiências e interesses, em vez de uma carta de direitos e obrigações. É uma cultura virtual multifacetada, como nas experiências visuais criadas por computadores no espaço cibernético ao reoorganizar a realidade. Não é fantasia, é uma força concreta [...] ( CASTELLS, 1999, p. 217).

A preocupação em entendermos o significado do termo "rede" corresponde ao que conhecemos sobre organização e integração de territórios e de mercados regionais, pela quebra de barreiras e obstáculos que promovam uma circulação de um todo, e principalmente de como essa ação afeta as relações, tanto em termos espaciais como também sociais.

Dias (2001), em suas reflexões, faz uma leitura da história das redes e caracteriza seus efeitos sobre a organização do território. Além disso, utiliza de diferentes autores para mostrar um conceito de rede. Formularam assim a gênese da criação de um sistema de comunicações e assim progressivamente toma forma um sistema geral de comunicações combinando estradas de ferro e canais em redes de primeira ordem e redes secundárias.

O que realmente significa nas reflexões a ideia de redes é a relação de território, ligada às necessidades do capital, a qual permita sempre a integração aos interesses de desenvolvimento em benefício da produção e fluxo de capital entre regiões de interesses em comum.

A rede é vista por alguns autores como um instrumento de poder utilizado pelos agentes dominadores mundiais. Estes são determinados principalmente pelos fluxos de mercadorias e de capitais que possuem lugar de conexão e de manifestações econômicas políticas e sociais que atuam articuladas entre si.

De acordo com Pretto (2006, P. 5), "Não podemos continuar a pensar que as redes se instalam sobre espaços vazios". "Ao contrário, afirma Leila Dias, as redes se instalam sobre uma realidade complexa, e não em espaços virgens" (1995, p. 148). Isso significa que não podemos nos contentar com simples apropriações dessas tecnologias, como se elas fossem, por si só, capazes de reverter situações. Por isso, precisa-se enxergar que essas potencialidades impulsionam elementos que, longe de serem unificadores, constituem-se em diferenciadores dos seres e de suas culturas, passando a polos geradores de novas articulações.

As novas articulações originárias da rede de tecnologia foram consideradas em muitos aspectos instrumento de inclusão social. Ou seja, significa que o cidadão à medida que possui acesso à 
tecnologia, está inserido no conjunto global de informação e comunicação, conjunto esse propiciado por celulares, computadores que o inserem a diversos contextos globalizantes de consumo e cultura. Isso pode significar um novo contorno, não mais como incorporação ao mercado, mas como incorporação à cidadania e ao mercado, garantindo acesso à informação e barateando os custos dos meios de produção multimídia através das novas ferramentas que ampliam o potencial crítico do cidadão. Como cidadãos e consumidores, emissores e receptores de saber e informação, seres ao mesmo tempo autônomos e conectados em redes, são a nova forma de coletividade.

Segundo Lemos (2009) a tecnologia é uma forma de inclusão social, ou seja, a aprendizagem da informática e 0 acesso às novas linguagens de comunicação e informação não só possibilitam oportunidades econômicas, de geração de renda, como também representam um importante capital social.

Conforme Lemos (2009), no Brasil existe uma grande demanda reprimida pela comunicação em rede. A concentração de renda, de um lado, e a pobreza da maioria da população, de outro, constituem enormes entraves para a expansão da internet e de seus serviços no país. Ao mesmo tempo, as comunidades e os indivíduos mais pobres percebem a importância da internet. Diversos programas da TV aberta têm disseminado reportagens sobre os benefícios da rede, o que elevou o interesse dos brasileiros pela comunicação mediada por computador. O potencial de conexão no país é bloqueado por fatores sociais e econômicos.

A informação eletrônica passa a ser acessada, consumida, produzida e distribuída de todo e qualquer lugar, a partir dos mais diferentes objetos e dispositivos. O ciberespaço começa assim a "baixar" para coisas e lugares, a "pingar" no "mundo real".

A metáfora do download mostra bem a atual ênfase da localização e da mobilidade física e informacional de pessoas, objetos e informações, ressaltando relações espaciais concretas nos lugares (públicos e privados). O download do ciberespaço cria uma nova territorialização do espaço, a territorialidade informacional. O lugar não é mais um problema para acesso e trocas de informação no ciberespaço "lá em cima", mas uma oportunidade para acessar informação a partir das coisas "aqui em baixo".

Lemos (2009) acrescenta que um café, uma praça, um mercado, dotados de sensores, dispositivos e redes sem fio continuam sendo Ciberespaço é aqui o nome genérico para as redes telemáticas. Um café, uma praça ou um mercado, só que transformados pela territorialidade informacional emergente. Este território informacional pode ser entendido pela imagem do ciberespaço "pingando" nas coisas, como uma membrana, uma pele eletrônico-digital acoplada aos lugares criando novas heterotopias.

As TICs constituem-se em métodos e formas de produção por meio de instrumentos sofisticados de redes e conexões que proporcionam a disseminação, a visualização, a utilização e a transformação de informação, no interesse de todos os seus utilizadores.

Mas quantos são os analfabetos digitais, aquelas pessoas despreparadas para viver a interação com as máquinas? A tecnologia é uma forma de inclusão social, isto é, a aprendizagem da informática e o acesso às novas linguagens de comunicação e informação não só possibilitam oportunidades econômicas, de geração de renda, como também representam um importante capital social.

Essa problemática foi evidenciada na atualidade, oriundas das dificuldades dos docentes e discentes ao manuseio das ferramentas e, até mesmo de acesso a internet, em meio a "Pandemia do Corona Vírus". O isolamento social de pessoas fez com que as escolas e universidades em todo mundo, e no Brasil impulsionassem os recursos do espaço virtual para ministrar aulas on-line, com um aumento significativo de uso das diversas mídias disponíveis.

A explicação para essa dificuldade de autonomia do aluno para aprendizagem pelas TICs, no Brasil pôde ser visualizada pela mídia em todo o país, a qual destacou a precariedade desses acessos, principalmente em virtude das desigualdades sociais regionais do país.

Segundo dados do IBGE (2018) os jovens entre 20 e 24 anos são o grupo mais conectado, com 88,4\% de toda a população do país nessa idade possuindo acesso à rede. Os smartphones continuam sendo o principal meio de acesso, com $97 \%$ das pessoas acessando a internet por meio de seus celulares. Já o acesso através do computador vem caindo: enquanto em 2016 cerca de $63 \%$ das pessoas acessavam a internet usando um computador, em 2017 esse número diminuiu para 56,6\% dos usuários.

Com a tecnologia móvel, a disseminação dos celulares leva a internet para a maioria da população: $79,9 \%$ dos brasileiros vivem em lares com internet, fixa ou móvel. Isso que dizer que 166 milhões de brasileiros já têm algum acesso à rede. Mesmo na população vivendo abaixo da linha de pobreza, $65,9 \%$ têm internet em casa, seja móvel ou fixa. 
A pesquisa do CETIC 1 (2018) revela que quase $80 \%$ dos alunos utilizam o celular como principal instrumento para acessar a internet. Sendo assim, a pesquisa do CETIC (2018) reafirma os dados do IBGE (2018) sobre o índice de estudantes da rede pública $(59,4 \%)$ da rede privada $(90,3 \%)$ com acesso a internet celular. Essa constatação de que, aproximadamente $60 \%$ dos estudantes da rede pública e, quase $100 \%$ dos estudantes da rede privada no Brasil podem ter acesso a essa tecnologia educativa, podemos deduzir que o celular com acesso a internet pode ser um instrumento didático-pedagógico ao ensino geográfico.

O acesso à internet e sua aplicação nas redes tornam-se relevantes por viabilizarem a troca de informação e comunicação instantânea, que chegam a todos os usuários. Contudo, essa troca, normalmente, não possui uma seleção prévia e classificatória de uso e retransmissão. Assim, a inclusão nas TICs não significa estar conectado ao mundo digital, porque a inclusão digital significa a compreensão da informação, da comunicação e a interpretação para que possamos produzir conhecimento e ele poder se dissipar pelas redes nos diversos espaços virtuais dispostos pelo mundo digital globalizado. Ao professor cabe a missão de administrar o conteúdo das TICs aos espaços escolares para direcioná-los aos estudantes de maneira inclusiva. Afinal:

\begin{abstract}
A mídia representa um campo autônomo do conhecimento que deve ser estudado e ensinado às crianças da mesma forma que estudamos e ensinamos a literatura, por exemplo: A integração da mídia à escola tem necessariamente de ser realizada nestes dois níveis: enquanto objeto de estudo, fornecendo às crianças e aos adolescentes os meios de dominar esta nova linguagem; e enquanto instrumento pedagógico, fornecendo aos professores suporte altamente eficaz para a melhoria da qualidade do ensino (BELLONI, 1991, p. 41).
\end{abstract}

De acordo com Belloni (2005) evidencia a importância do papel da integração das TICs na escola. Para essa autora, existem sete razões para isso, que dentre elas abordam questões relativas ao consumo elevado de mídias e a saturação do mesmo; a importância ideológica das mídias e a influência da publicidade; o crescimento da comunicação visual e a expectativa dos jovens para serem formados para entenderem sua época. Ou seja, essas razões evidenciam uma preocupação para formar uma postura crítica perante elas mesmas, perante o seu crescimento desenfreado. Portanto:

\begin{abstract}
A escola deve integrar as tecnologias de informação e comunicação porque elas já estão presentes e influentes em todas as esferas da vida social, cabendo à escola, especialmente à escola pública, atuar no sentido de compensar as terríveis desigualdades sociais e regionais que o acesso desigual a estas máquinas está gerando. (BELLONI, 2005, p.10).
\end{abstract}

A autora esboça a relação de trabalho pedagógico e a integração com as tecnologias, traçando um quadro relativo à produção de materiais pedagógicos e à concepção de unidades de aprendizagem relacionando o conceito de mediatizar.

Sobre as tecnologias e educação a Agenda 2030, lançada pela Organização das Nações Unidas (ONU), os Objetivos de Desenvolvimento Sustentável- ODS 4 (quatro) traz para a educação questões envolvendo a infraestrutura das escolas, a oferta de recursos para apoiar países menos desenvolvidos e a criação de garantias para que os professores tenham boas condições de trabalho e reconhecimento social. Para o Brasil até 2020, para o ensino superior, incluir programas de formação profissional, de tecnologia da informação e comunicação.

A Resolução CNE/CP № 2, de 20 de dezembro de 2019 define as Diretrizes Curriculares Nacionais para a Formação Inicial de Professores para a Educação Básica e institui a Base Nacional Comum para a Formação Inicial de Professores da Educação Básica (BNC-Formação). Esta Resolução traz para os Cursos de Licenciatura no Art. 10, que todos os cursos em nível superior de licenciatura, destinados à Formação Inicial de Professores para a Educação Básica, serão organizados em três grupos, com carga horária total de, no mínimo, 3.200 (três mil e duzentas) horas, e devem considerar o desenvolvimento das competências profissionais explicitadas na BNC-Formação, instituída nos termos do Capítulo I. Ou seja, deve considerar a BNCC e a BNC.

Sobre a temática das TICs e educação abordada nas reflexões supracitadas nesse texto, a Resolução CNE/CP № 2, de 20 de Dezembro de 2019 aponta no Art. 12, do Grupo I, que a carga horária de 800 horas deve ter início no $1^{\circ}$ ano, a partir da integração das três dimensões das competências

\footnotetext{
${ }^{1}$ CETIC: Com a missão de monitorar a adoção das tecnologias de informação e comunicação (TIC) - em particular, o acesso e uso de computador, Internet e dispositivos móveis - foi criado em 2005 o Centro Regional de Estudos para o Desenvolvimento da Sociedade da Informação (Cetic.br). O Cetic.br é um departamento do Núcleo de Informação e Coordenação do Ponto BR (Nic.br), que implementa as decisões e projetos do Comitê Gestor da Internet do Brasil (Cgi.br). Disponível em: https://cetic.br/pesquisa/educacao/. Acesso em: abril de 2019.
} 
profissionais docentes - conhecimento, prática e engajamento profissionais - como organizadoras do currículo e dos conteúdos segundo as competências e habilidades previstas na BNCC- Educação Básica para as etapas da Educação Infantil, do Ensino Fundamental e do Ensino Médio. Assim, o Parágrafo único do Grupo I, determina currículos e seus marcos legais, e realização de trabalho e projetos que favoreçam as atividades de aprendizagem colaborativa; Compreensão básica dos fenômenos digitais e do pensamento computacional, bem como de suas implicações nos processos de ensino-aprendizagem na contemporaneidade;

No art. 13, do grupo II compreende o aprofundamento de estudos na etapa e/ou no componente curricular ou área de conhecimento, a carga horária de 1.600 horas deve efetivar-se do $2^{\circ}$ ao $4^{\circ}$ ano, segundo os três tipos de cursos. Assim, o $\S 1^{\circ}$ Dos estudos comuns, devem ser incluídas, nas 1.600 horas, as seguintes habilidades: IV - vivência, aprendizagem e utilização da linguagem digital em situações de ensino e de aprendizagem na Educação Básica.

Portanto, a Resolução CNE (2019) traz orientações para a carga horária de formação de professores voltada as TICs, no Parágrafo único, a organização curricular a luz das competências e habilidades previstas na BNCC, distribuídas dentre às 800 horas do curso. No art. 13, do grupo II, incluída nos aprofundamentos de estudos na etapa e/ou no componente curricular ou área de conhecimento, distribuída dentre a carga horária de 1.600 horas deve efetivar-se do $2^{\circ}$ ao $4^{\circ}$ ano, segundo os três tipos de cursos.

A Portaria no 1.329 de 27 de março de 2020, altera a Portaria ํㅡ 1.122, de 19 de março de 2020, e define as prioridades, no âmbito do Ministério da Ciência, Tecnologia, Inovações e Comunicações (MCTIC), no que se refere a projetos de pesquisa, de desenvolvimento de tecnologias e inovações, para o período 2020 a 2023. O Parágrafo único, diz que são também considerados prioritários, diante de sua característica essencial e transversal, os projetos de pesquisa básica, humanidades e ciências sociais que contribuam para o desenvolvimento das áreas definidas nos incisos I a $\mathrm{V}$ do caput.

Dentre as sete competências da Geografia na Base Nacional Comum Curricular - BNCC (2018), para o ensino fundamental cinco está relacionada de alguma forma com a tecnologia. A de número 2 (dois) que pontua a importância de estabelecer conexões entre diferentes temas do conhecimento geográfico, reconhecendo a importância dos objetos técnicos para a compreensão das formas como os seres humanos fazem uso dos recursos da natureza ao longo da história.

A 3 (três) no sentido de buscar desenvolver autonomia e senso crítico para compreensão e aplicação do raciocínio geográfico na análise da ocupação humana e produção do espaço, envolvendo os princípios de analogia, conexão, diferenciação, distribuição, extensão, localização e ordem.

A 4 (quatro) que chama atenção para desenvolver o pensamento espacial, fazendo uso das linguagens cartográficas e iconográficas, de diferentes gêneros textuais e das geotecnologias para a resolução de problemas que envolvam informações geográficas. E, a competência cinco em desenvolver e utilizar processos, práticas e procedimentos de investigação para compreender o mundo natural, social, econômico, político e o meio técnico-científico e informacional, avaliar ações e propor perguntas e soluções (inclusive tecnológicas) para questões que requerem conhecimentos científicos da Geografia.

A BNCC (2019) para ao ensino médio resgata as orientações das competências para o ensino fundamental e acrescenta que as tecnologias digitais apresentam apelos consumistas e simbólicos capazes de alterar suas formas de leitura de mundo, práticas de convívio, comunicação, participação política e produção de conhecimento, interferindo efetivamente no conjunto das relações sociais.

A sociedade se direciona, cada vez mais para os usos das TICs no dia a dia, em serviços diversos, tais como, bancários, trabalhos remotos de geral e diversos instrumentos de lazer.

Recentemente foi considerado viável o uso das TICs no Exame Nacional do Ensino Médio- ENEM, que de acordo com o MEC (2020) esse exame terá aplicação digital a partir desse ano.

No primeiro ano, a aplicação do Enem digital ocorrerá em modelo piloto. A implantação será progressiva, com início no próximo ano e previsão de consolidação em 2026. Com essa nova versão, por meio de computador, o governo federal pretende realizar o exame em várias datas ao longo do ano, por agendamento. Do ponto de vista técnico, o Enem Digital vai permitir a utilização de novos tipos

Caminhos de Geografia $\quad$ Uberlândia-MG $\quad$ v. 22, n. 81 jun./2021 $\quad$ p. 196-216 Página 206


de questões com vídeos, infográficos e até a lógica dos games. Também será possível aplicar o Enem em mais municípios.

Diante desse cenário, é necessário oportunizar o uso e a análise crítica das diversas tecnologias, explorando suas potencialidades e evidenciando seus limites na configuração do mundo atual.

\section{DESAFIOS PARA O ENSINO NO ESPAÇO VIRTUAL NA FORMAÇÃO DE PROFESSORES DE GEOGRAFIA NO NORTE DO TOCANTINS}

Neste trabalho, buscamos a análise das TICs no ensino, a partir da universidade federal do TocantinsUFT, na formação de professores, em específico a partir das experiências no curso de Geografia da Universidade Federal do Tocantins.

O curso de Geografia foi autorizado pelo Decreto Presidencial no 91.507, de 5 de agosto de 1985 (DOU, 1985) e pela Resolução no 030, de 21 de fevereiro de 1985, do Conselho Estadual de Goiás. Em 1992, o Curso de Geografia foi reconhecido pela Portaria oㅜ 1.366, de 16/9/1992, do Conselho Federal de Educação (PPC, 2009).

O curso em tela está situado na cidade de Araguaína no norte do Tocantins, esta cidade possui uma localização estratégica no Norte do Tocantins, porque possui limites fronteiriços com os Estados do Maranhão e do Pará. Sendo assim, essa cidade torna-se atrativa e recebe muitos estudantes, tanto para a educação básica quanto para o ensino superior, tornando-se uma instituição de referência no ensino superior público, no contexto regional no norte do estado do Tocantins.

Dados de pesquisa e extensão, com resultados publicados em livro e artigo em periódico, sobre as TICs e ensino, realizadas na UFT ${ }^{2}$ mostram que a maioria dos estudantes do curso de Geografia dessa universidade possui acesso as TICs e internet através dos celulares. Contudo, não há uma participação efetiva desses estudantes nas ações do curso realizadas na modalidade on-line.

Um levantamento realizado pela coordenação do curso de Geografia (2020) para diagnosticar como está a situação dos estudantes desse curso em tempos de pandemia, utilizando da metodologia de questionário on-line, identificou que a maioria dos estudantes possui de alguma forma acesso à internet.

Destacamos desse questionário as respostas de número 6 (seis), 7 (sete) e 8 (oito).

A questão seis apresenta os principais meios de acesso à internet que os estudantes do curso possuem.

Gráfico 1 - Questão ํํ 6: Como ocorre seu acesso à internet?

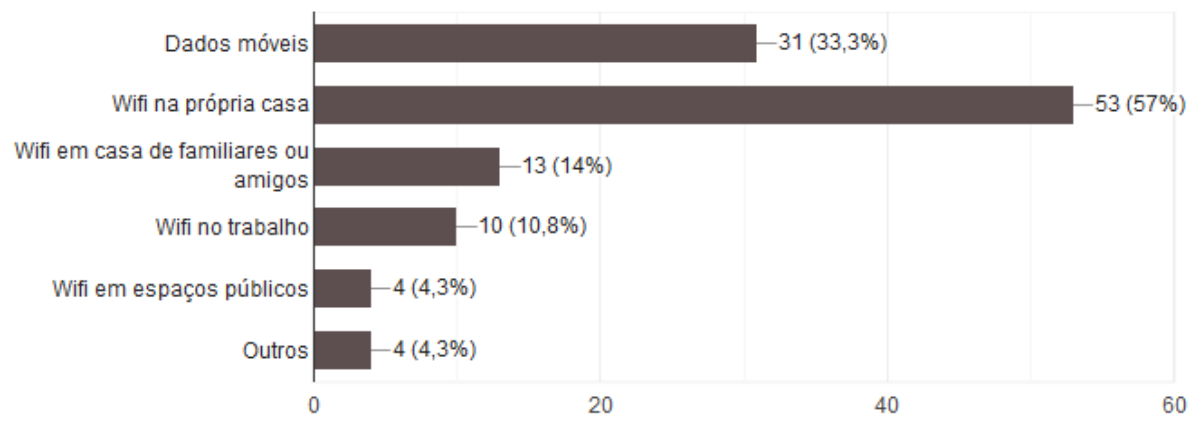

Fonte - Coordenação do curso de Geografia (2020).

\footnotetext{
2 Tecnologias de Informação e Comunicação-TIC: Possibilidade didática para a Formação inicial de professores de Geografia no norte do Tocantins In: Geografias tocantinenses e outras leituras.01, 2019, p.143.

Formação de professores de Geografia na Amazônia: TIC e Ensino no Norte do Tocantins. Revista Ciencia Geográfica, AGB BAURÚ. São Paulo. 2020.

Caminhos de Geografia

Uberlândia-MG

v. 22, n. 81

jun./2021

p. $196-216$

Página 207
} 
O gráfico 1 revela que $57 \%$ dos estudantes do curso de Geografia possui wifi na própria casa. Ou seja mais de $50 \%$ dos estudantes tem acesso à internet em casa.

Gráfico 2 - Questão oำ : Quais os recursos tecnológicos você possui para uso em sua residência?

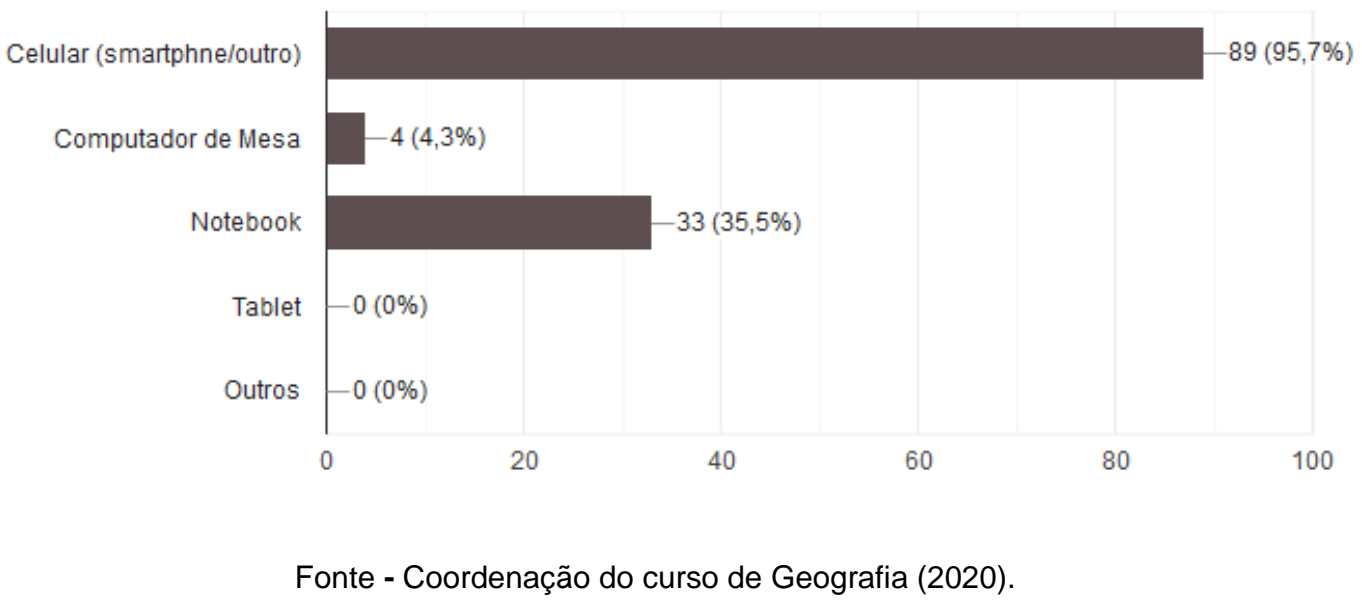

O grafico 2 mostra que 95\% dos estudantes do curso de Geografia possui aparelho celular. No entanto, menos de $40 \%$ desses estudantes não possui computador.

Gráfico 3 - Questão no 8: Qual o principal meio de informação pelo qual você está acompanhando os desdobramentos da Pandemia (Coronavírus//Covid-19)?

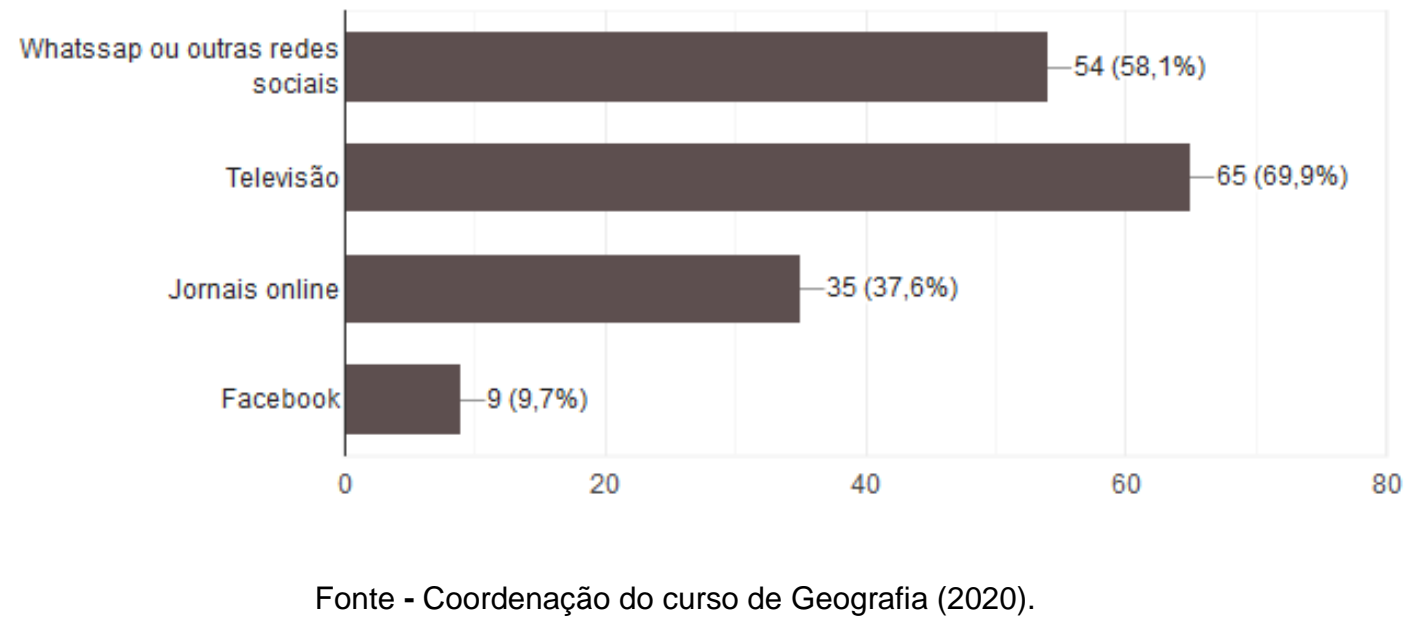

O gráfico 3 evidencia que mais de $50 \%$ dos estudantes do curso de Geografia possui acesso à internet via celulares, participando de redes sociais, utilizando a interação e comunicação por meio do WhatsApp.

Ao considerarmos os resultados obtidos no questionário, precisamos levar em consideração o número de matriculados no curso em 2020, de 240 estudantes, com 93 respostas ao questionário. Esse número de resposta corresponde a 38\% dos estudantes. Dessa forma, podemos perceber que menos de $40 \%$ dos estudantes participaram desse processo. Ou seja, mais de $60 \%$ dos estudantes não responderam ao questionário.

Esse quadro nos induz a algumas indagações, tais como, por que menos de $40 \%$ dos estudantes do curso não responderam as questões? Qual a realidade de acessos a internet, para a maioria dos estudantes do curso de Geografia ou para os estudantes da UFT do campus Araguaína, de modo geral?

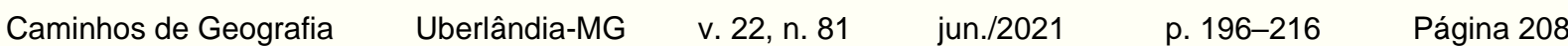


Em virtude das características do Estado do Tocantins, conforme dados do IBGE (2019), considerada predominantemente rural, e muitos dos estudantes residirem em municípios e, em áreas rurais próximas a cidade de Araguaína, podemos intuir que muitos desses estudantes, em virtude da pandemia retornaram as suas residências, e estão em áreas rurais de difícil acesso à internet, possuem acesso precário, ou não possuem acesso a internet.

Por outro lado, conforme dados do IBGE, IDH ${ }^{3}$ e outros órgãos de pesquisa, existe disparidades socioeconômicas regionais no país, que podem explicar diversas ausências de políticas públicas, em infraestrutura, de modo geral e, principalmente a falta de acessos a tecnologia no estado e, principalmente no norte do Tocantins.

Contudo, apesar das dificuldades de muitos estudantes, a UFT e o curso de Geografia não possuem condições de se ausentar do cenário de oportunidades ofertado em tempos de pandemia, amplamente utilizados pelas instituições de educação em todo o país, de ofertar a inserção dos estudantes ao Ensino Remoto, utilizando-se das possibilidades das TICs, na modalidade on-line.

Nesse cenário o curso de Geografia realizou seleção de bolsas, PIBIC, PIVIC, Monitoria em Tecnologias digitais e outros, em todas as etapas, realizadas de forma on-line, inclusive com entrevista de estudantes. Conforme uma das professoras orientadoras de um dos projetos no colegiado, Lessio, (2020) foi observado nesse processo muita dificuldade de alguns estudantes, que em virtude da precariedade de acesso à internet houve interrupção, várias vezes da entrevista.

Outros processos de seleção de ensino, pesquisa e extensão estão em andamento na UFT, e tudo indica que a opção mais viável, nesse período seja a sua realização, majoritariamente on-line.

Nos dias 08 e 09 de junho de 2020, o curso de Geografia realizou o I seminário on-line de Geografia do campus Araguaína. $O$ objetivo desse evento foi mostrar as atividades e os resultados de pesquisa e extensão realizadas no curso, durante o período de pandemia.

Os debates do dia 08 giraram em torno dos resultados do diagnóstico, sobre a situação dos estudantes durante a pandemia, que foi realizado pelo curso; os avanços e desafios para o curso na formação de professores mediante as especificidades regionais e as emergências do Ensino Remoto, voltado para as aulas on-line, no cenário nacional e apresentação geográfica de dados do avanço do "Coronavírus" no contexto regional do estado do Tocantins.

Pudemos observar a presença de aproximadamente 66 (sessenta e seis participantes), dentre esses participantes estavam, estudantes e professores do colegiado e professores egressos do curso. Obtivemos contribuições significativas para a formação inicial e continuada de professores, demonstradas, por meio de relatos de experiências de professores de Geografia e coordenadores, desenvolvidos em escolas da educação básica na cidade de Araguaína.

Nos debates de 09 de junho, observamos a presença de aproximadamente 77 (setenta e sete participantes) apresentaram resultados de pesquisa sobre a situação da Pandemia no estado do Tocantins e sua problemática no contexto regional. E, principalmente abordando as dificuldades de interpretação dos dados disponíveis para pesquisa do Covid-19 disponíveis para pesquisa nos sites oficiais.

Apesar das dificuldades de análise de dados, houve contribuição para a compreensão do avanço da doença na região norte desse estado, em especial nos vales dos rios Araguaia e Tocantins ao serem apresentados motivos de expansão do Covid-19, relativos à malha rodoviária com seus limites fronteiriços com os estados do Maranhão e Pará.

Os resultados do I Seminário on-line de Geografia de Araguaína se mostraram positivo, ao contribuir para desmistificar o medo do uso das Tecnologias digitais de muitos estudantes e, até mesmo de muitos professores.

A avaliação do I seminário on-line de Geografia, composta por 12 questões foi disponibilizada e obtemos respondas de 25 dos participantes. Destacamos as questões mais relevantes a essa discussão. As respostas sobre o acesso a plataforma nos mostraram que a maioria dos participantes possui habilidade para lidas com os instrumentos (vide Gráfico 4).

${ }^{3}$ Dados disponíveis em: Formação de professores de Geografia na Amazônia: TIC e Ensino no Norte do Tocantins. Revista Ciencia Geográfica, AGB BAURÚ. São Paulo. 2020. 
Gráfico 4 - Você teve dificuldade no acesso a plataforma Google Meet?

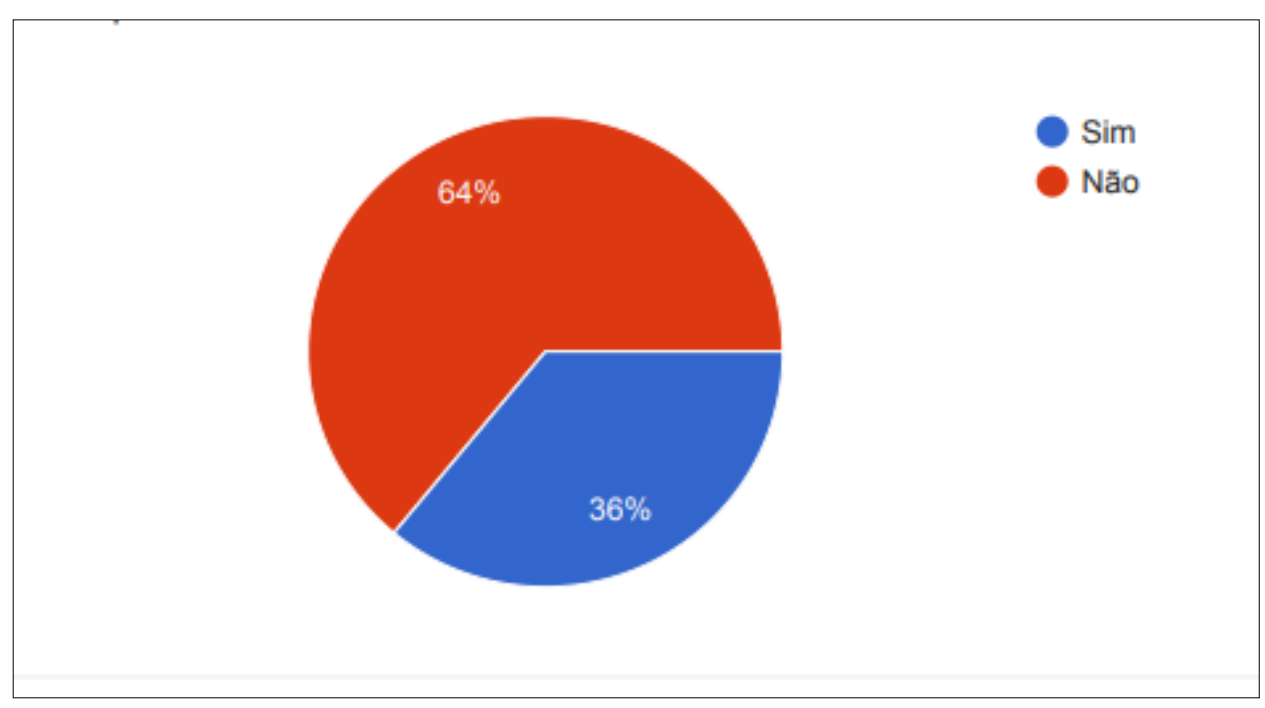

Fonte - Coordenação do curso de Geografia (2020).

A questão disponível no Gráfico 4, sobre o tipo de instrumento utilizado para o acesso a internet mostrou que a maioria dos participantes do seminário, $76 \%$ destes possui wifi na própria residência, $20 \%$ depende de familiares e amigos para ter acesso a internet e poucos conseguiram participar do evento com o acesso a internet, apenas por meio de dados móvéis dos celulares.

Essa informação nos permite afirmar que os estudantes incluidos na educação pelas TICs, são aqueles que possuem condições socieconomicas suficientes, para possuir acesso a internet de qualidade em seu domicílio.

Gráfico 5 - Como ocorreu seu acesso à internet para participar do evento?

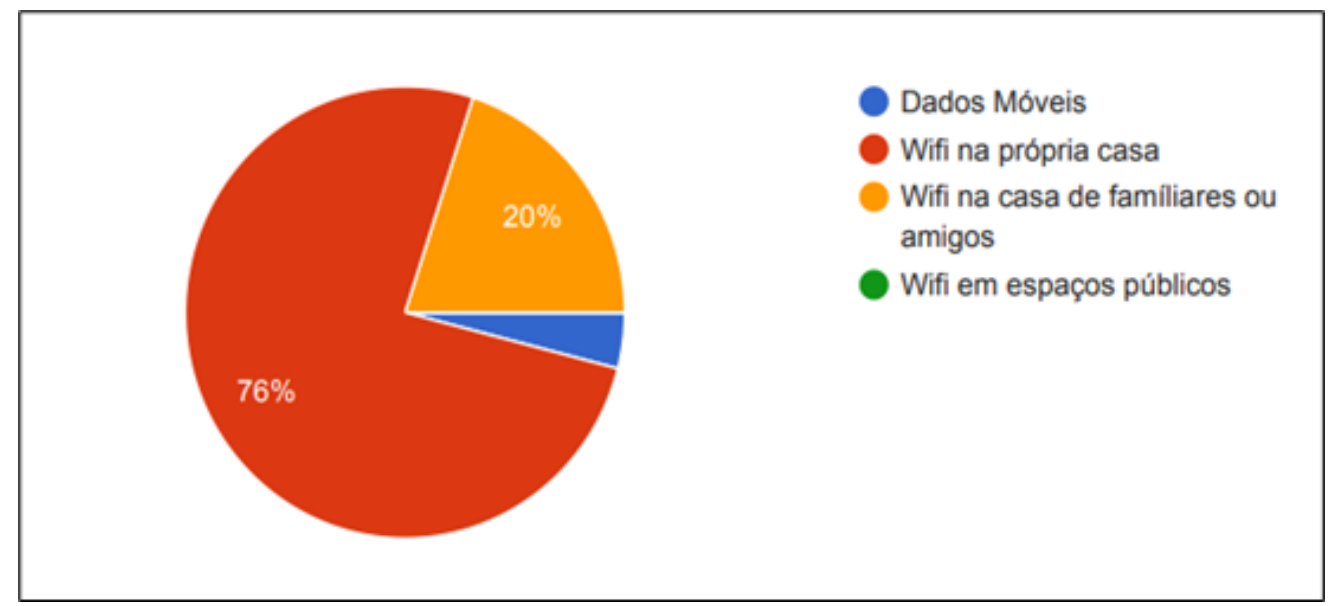

Fonte - Coordenação do curso de Geografia (2020).

A precariedade socioeconômica regional pode indicar ausências, significativas de muitos estudantes nos eventos on-line, mas por outro lado, nos permite afirmar que estamos nos adaptando e desbravando caminhos para buscar a inserção às TICs.

Acrescentamos que o curso de Geografia se insere na lógica do Ensino Remoto, seguindo os desdobramentos da Universidade de modo geral, que durante o período de pandemia alavancou, e segue ofertando diversos eventos e aulas on-line, por intermédio dos seus diversos cursos de graduação (Vide quadro 1). 
Quadro 1 - Eventos on-line na UFT (meses de abril, maio e junho, 2020).

\begin{tabular}{|c|c|c|}
\hline ABRIL & MAIO & JUNHO \\
\hline $\begin{array}{l}\text { Projeto Roteiro Geo-Turístico } \\
\text { promove live sobre patrimônio, } \\
\text { geografia e turismo } \\
\text { Professores preparam lives para } \\
\text { discutirem o Dia Mundial de } \\
\text { Conscientização do Autismo }\end{array}$ & $\begin{array}{l}\text { Roteiro Geo-turístico apresenta } \\
\text { Porto Nacional através de } \\
\text { transmissões na internet. } \\
\text { 4 Encontro do I Seminário } \\
\text { Online do Curso de Direito } \\
\text { Bate-papo discute o Inglês } \\
\text { como Língua Franca e } \\
\text { Interculturalidade. } \\
\text { Projeto Roteiro Geo-Turístico } \\
\text { promove live sobre patrimonio, } \\
\text { Geografia e turismo. } \\
\text { Projeto virtual "Segundas } \\
\text { Geográficas" apresenta live } \\
\text { sobre os tempos da Covid-19 } \\
\text { Semana do Zootecnista é } \\
\text { comemorada em lives com } \\
\text { profissionais da produção } \\
\text { animal }\end{array}$ & 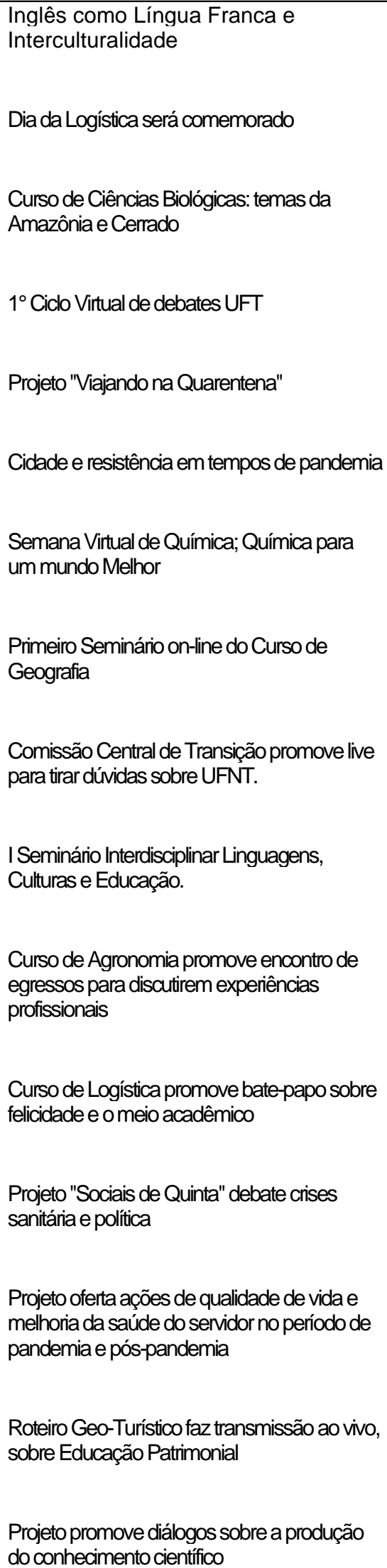 \\
\hline
\end{tabular}

Fonte - Adaptado pela autora. Disponível em https://ww2.uft.edu.br/index.php/-noticias. Acesso, junho de 2020. 
O quadro 1 mostra alguns eventos on-line que aconteceram e estão previstos na UFT, no mês de abril, maio e junho. Realizamos o levantamento de 29 (vinte e nove) eventos, dentre estes lives, Seminários, videoconferências e outros. Observamos que no mês de junho houve um aumento expressivo no número de eventos. Se compararmos ao número de eventos presenciais, antes da pandemia (disponíveis na página da UFT) realizados no mês de março (máximo dois ou três eventos) ao número dos eventos on-line realizados pela UFT, dispostos no quadro 1, notamos um aumento significativo.

Notamos também, que os eventos on-line estão presentes na maioria dos campi e cursos da UFT. Portanto, existe o desafio do curso de Geografia e da universidade, em inserir os estudantes excluídos desse processo.

Seguindo no propósito de entender às possibilidades das TIC, e na tentativa de compreender o contexto atual de Ensino Híbrido e Remoto, em meio as atividades realizadas no espaço virtual, a UFT busca o entendimento conceitual e didático-pedagógico nessa temática, realizando no dia 04 de junho de 2020 pela Diretoria de Tecnologias Educacionais (DTE) realizou o $1^{\circ}$ Ciclo Virtual de debates UFT ${ }^{4}$. A ideia desse ciclo é de debates, que seja um espaço de interação dialógica sobre experiências, possibilidades e estratégias didáticas que podem ser assumidas no exercício docente mediado por tecnologias.

Nesse primeiro encontro, os debatedores discutiram sobre essa temática, suas possibilidades e perspectivas. Foram convidados os pesquisadores José Moran (USP), José Valente (UNICAMP), Marco Silva (UERJ), Graça Moreira (PUC-SP), com mediação de Ana Medeiros (UFT) e Suzana Gilioli (UFT).

A fala desses professores trouxe novas reflexões sobre a realidade das TICs, o ensino e os desafios para as instituições e a UFT em tempos de Pandemia.

Os professores trouxeram suporte conceitual sobre o termo Ensino Híbrido e Ensino Remoto, destacando que o ensino híbrido não significa a transposição do ensino presencial para a modalidade EaD on-line. Essa forma de ensino consiste em uma mistura dessas duas modalidades, sendo parte oferecida presencialmente e a outra parte on-line.

Silva (2020) pontuou que a cibercultura vem favorecer os clássicos teóricos, em uma mediação competente, contudo há uma ausência das instituições mediante as dificuldades dos estudantes, pois há um descompasso em construir caminhos para o acolhimento dos estudantes inseridos na realidade das TICs.

Moreira (2020) advertiu que a pandemia é responsável pela evasão de muitos estudantes, pois a Educação Remota on-line foi uma realidade emergente, que surgiu sem tempo de preparação para um movimento de transposição presencial para o on-line. Contudo, houve um grande engajamento dos professores que abraçaram a causa na busca da fluência tecnológica. A professora sugere que para ensinar e aprender as tecnologias é necessário aprendermos com outras universidades, repensarmos a função social da universidade e promover encontros pedagógicos para planejar e dar voz aos professores, estudantes e comunidade. Dessa forma devemos pensar o currículo flexível de ressignificação do saber pedagógico.

O professor Valente (2020) trouxe reflexões sobre sua preocupação com a fragilidade da infraestrutura de acesso à internet de muitos estudantes e a precariedade de fluência digital dos professores que produzem vídeos e outros materiais didáticos, os quais estão sendo disponibilizados a educação. Para esse professor os recursos produzidos pobres, de baixa qualidade metodológica pode prejudicar o ensino aprendizagem. Assim, as instituições devem capacitar os professores para o uso das TICs, no Ensino Híbrido sem deixar de pensar na realidade social do estudante.

Moran (2020) Destaca que a discussão sobre o Ensino Híbrido, já acontece a aproximadamente 20 anos no Brasil, assim, não é um debate novo, mas ainda segue em passos lentos. Ele chama a atenção para o diálogo interno e definição de estratégias locais, no sentido de repensar o currículo, em uma construção conjunta integradora entre a comunidade acadêmica e institucional.

Moran (2020) Aponta desafios para a universidade pública, tais como a desigualdade social que torna possível para poucos o acesso a uma aula invertida e personalizada e para muitos não, de preparar o estudante para o futuro profissional de trabalho remoto, home Office, e o desafio de descobrir o que faz sentido presencial e on-line no currículo mediante a mistura de metodologia, tempo e espaço. Esse

${ }^{4}$ O evento foi realizado no Canal do YouTube da DTE - https://www.youtube.com/user/EstudioDTE e no Facebook da DTE. 
professor conclui que para os estudantes terem uma chance no futuro profissional as instituições devem produzir meios para formação docente que aprenda a lidar com o Ensino Híbrido.

A professora da UFT representante da UFT Ana Medeiros (2020) afirmou que aproximadamente 50\% dos estudantes da UFT não possuem computador em casa e cerca de $30 \%$ desses estudantes não possuem acesso à internet.

A afirmação da professora Ana Medeiros (2020) sobre o percentual de estudantes da UFT que não possuem acesso a internet em casa, corrobora com respostas as indagações sobre os motivos, pelos quais menos de $40 \%$ dos estudantes do curso de Geografia responderam ao questionário, citado anteriormente no texto.

Outras afirmações realizadas pelos professores sobre a precariedade de fluência digital de muitos professores e a fragilidade na infra-estrutura de acessos as TICs distribuídos no contexto regional do Brasil, confirmam a nossa reflexão sobre os motivos das ausências da muitos estudantes as atividades on-line que a universidade tem ofertado.

As preocupações com essas ausências são motivos de reflexões para a universidade, de modo geral e para nós, enquanto professora do curso de Geografia nessa universidade. O debate sobre as formas de inserção dos estudantes as TICs têm motivado a realização de proposta de pesquisa, extensão, mini-cursos e reuniões constantes no colegiado de Geografia, na busca de caminhos didáticopedagógicos para o acolhimento dos estudantes que estão excluídos de todo esse processo.

Seguindo nesse propósito a professora Ana Medeiros (2020), ao solicitar sugestões aos professores presentes no debate, sobre quais as maneiras de contribuir com a formação de professores, que doravante estarão cada vez mais inseridos na modalidade de Ensino Híbrido e Remoto, em todo o país a partir da pandemia, colaborou com a interpretação positiva das nossas ações, ao nos mostrar que estamos no caminho certo na busca da melhoria do ensino geográfico a luz das TICs.

Destacamos que as sugestões dos professores, sobre o Ensino Híbrido e Remoto inserido na realidade socioeconômica, em específico para o público da Universidade Federal do Tocantins, no norte desse Estado, seguem nessa direção. Ou seja, é necessária a formação digital para professores, há uma emergência de mudança mental na forma de ensinar e aprender com foco na aprendizagem ativa e usos das TDICs. E, principalmente a instituição deve pensar o Plano de Desenvolvimento Institucional - PDI e Currículo para formação inicial e continuada de professores, direcionadas a busca coletiva de parcerias junto à comunidade local, em torno da educação com uso das diversas tecnologias.

Sobre Aas TDICs, na perspectiva de Valente (2014), a universidade vem buscando debates e iniciativas com oferta de cursos de Formação continuada tais como, o Curso Contemporaneidade, Docência e Comunicação digital e Programas voltados a inclusão digital de professores da UFT, o Programa de Monitoria em Tecnologias digitais, que contempla atividades de caráter didáticopedagógicas desenvolvidas pelos monitores, e orientadas por professores coordenadores dos cursos da UFT. Essa Monitoria coopera para a formação acadêmica na Universidade, ao propiciar aos estudantes monitores a oportunidade de ampliar os conhecimentos em tecnologias educacionais digitais, proporcionando uma futura formação profissional qualificada e a ressignificação do processo de ensino-aprendizagem, mediado por tecnologias inserido no espaço virtual.

Assim, podemos concluir que há materializado na universidade e no curso de Geografia-UFT, a dificuldade de estudantes e muitos professores no manuseio efetivo dos diversos instrumentos disponibilizados pelas TDICs. Na contramão dessa problemática há um movimento crescente, em busca da utilização, cada vez maior do ensino incorporado as TICs, no espaço virtual. Ou seja, apesar da falta de destreza e dificuldades discente e docente no manuseio das ferramentas digitais, há o aumento na promoção de eventos e aulas na modalidade on-line na UFT.

Portanto, torna-se necessário empreender maior esforço na busca de caminhos, para amenizar a exclusão de muitos estudantes e de professores ao ensino Híbrido e Remoto na educação regional norte tocantinense.

\section{CONSIDERAÇÕES FINAIS}

Ao refletirmos sobre as TICs na educação no Norte do Brasil, buscamos não apenas mostrar as desigualdades que coexistem entre a educação presencial e on-line em meio à pandemia. Mais do que 
isso, debruçou-se no propósito de impulsionar o debate e dar visibilidade ao descaso com a educação à luz das emergências das Tecnologias, de modo geral que seguem inseridas na problemática regional.

Ou seja, notamos que na atualidade, em virtude da utilização do Ensino Híbrido e Remoto em todo o Brasil, as condições socioeconômicas regionais podem estar atreladas ao grande número de estudantes excluídos da educação. De acordo com dados oficiais do país, o norte do Estado do Tocantins conta com situações precárias, visualizadas por meio de escolas fragilizadas e a ausência de políticas públicas efetivas para a inclusão social e, consequentemente a exclusão digital de muitos estudantes.

Com efeito, pensar estratégias para inclusão digital no contexto regional brasileiro, vai além dos acessos as TICs, coexistem necessidades da melhoria socioeconômica como um todo. Contudo, na atualidade, em meio a pandemia e o isolamento social, a exclusão digital traz à tona a perda do acesso ao conhecimento e a qualidade no ensino e aprendizagem de muitos estudantes.

Nesse sentido, admite-se que a educação para as TICs no Norte do Tocantins possui especificidades, excludentes, em virtude da carência de infraestrutura básica, como o acesso à energia, a laboratórios de informática, a recursos humanos e, sobretudo, à internet. A identificação dessa problemática consegue englobar amplas formas de debates na busca de estratégias que pretendem minimizar as diferenças e, de certa forma atrelar os pressupostos teóricos a prática do Ensino Híbrido e Remoto ao desenvolvimento de ações sociais mais inclusivas.

A atualização tecnológica de professores e a fluência digital de estudantes se mostram emergentes, diante da conjuntura dessa conjuntura tecnológica voltadas a educação, mediante a pandemia e do isolamento social. Ou seja, a busca por enfrentar as desigualdades regionais perpassa por um tratamento igual no investimento de recurso humano e tecnológico.

Evidenciamos a partir dessa análise a urgência de políticas públicas para o acesso à internet domiciliar, como essencial a inclusão social e ao desenvolvimento socioeconômico regional através da promoção da educação, que cada vez mais se apresenta ao Ensino Híbrido, inserida nos diversos espaços virtuais de aprendizagem. Principalmente, no Pós-pandemia, mediante o abandono do Ensino Remoto e retorno as aulas presencias, nas diversas instituições de ensino.

Dessa forma, entendemos que a inclusão efetiva as TICs vão para além da disponibilização de aparelhos digitais e capacitação docente e discente a fluência digital as TDICs. A qualidade da educação está diretamente relacionada às possibilidades estruturais dos instrumentos oriundas das tecnologias atuais, mormente em torno da informação e da partilha do conhecimento nas redes digitais. Portanto, essas redes, atreladas às especificidades locais, podem ser fundamentais ao processo de ensino-aprendizagem.

Para além da crítica, há um movimento positivo do curso de Geografia e da UFT para aglutinar ideias a propostas construtivas, criando possibilidades de adaptação as TICs via Ensino Híbrido e ao Ensino Remoto. Contudo, precisa ser condizente a realidade socioeconômica do público atendido nessa universidade.

As alternativas de inclusão podem seguir em várias direções, entretanto, inicialmente, sem sombra de dúvidas torna-se necessário a formação digital para professores. Concordamos que há iniciativas para a inclusão digital, porém de forma tímida. Portanto, há uma emergência de mudança mental na forma de ensinar e aprender com foco na aprendizagem ativa e usos das diversas tecnologias voltadas a educação.

Ademais, as benesses das tecnologias são instrumentos didático-pedagógicos importantes na melhoria da qualidade da educação regional. Portanto, esse assunto não se esgota, mas podemos por hora concluir que a UFT deve juntamente com a comunidade acadêmica e, em geral discutir e pensar metas e ações emergenciais, para a formação inicial e continuada de professores inserida nas TICs e as TDICs, de modo geral voltadas ao ensino. E, principalmente empreender esforços nessa direção, para construção do Plano de Desenvolvimento Institucional - PDI e currículo, entrelaçados às especificidades regionais norte tocantinense.

\section{REFERENCIAS}

BELLONI, M. L. A formação na sociedade do espetáculo. São Paulo: Edições Loyola, 2005. 
Educação para a mídia: missão urgente da escola. São Paulo: Comunicação \& Sociedade, v. 10, n. 17, p. 36-46, 1991.

BRASIL. Ministério da Educação. Base Nacional Comum Curricular. BNCC. Disponível em http://basenacionalcomum.mec.gov.br/. Acesso em outubro de 2019.

BRASIL. Lei no 9.394, de 20 de dezembro de 1996. Estabelece as diretrizes e bases da educação nacional. Diário Oficial da União, Brasília, ano 84, n. 248, p. 27833-27841, 1996.

CASTEL, R. As metamorfoses da questão social: uma crônica do salário; tradução de Iraci D. Poleti, Petrópolis, RJ: Vozes, 1998.

CASTELLS, M. 1942. A Galáxia da Internet: Reflexões sobre a internet, os negócios e a sociedade; tradução Maria Luiza X. de A. Borges; revisão Paulo Vaz- Rio de Janeiro: Jorge Zahar. Ed. 2003.

A Sociedade em Rede. Tradução: Roneide Venâncio Mojer.-A Era da Informação; Economia,Sociedade e Cultura; V.10. São Paulo: Paz e Terra, 1999.

DIAS, L. C. Redes: emergência e organização. In: CASTRO, Iná Elias; GOMES, Paulo Cesar da Costa; CORRÊA, Roberto Lobato (Orgs.). Geografia: conceitos e temas. Rio de Janeiro: Bertrand Brasil, 1995. p. 141-162.

FERNANDES, F. 1920. A Revolução Burguesa no Brasil; ensaio de interpretação sociológica/ 3. Ed. Rio de Janeiro: Guanabara, 1987.

FERREIRA, J. Lugar, espaço e Geografia do real ao virtual na sociedade do conhecimento. Lisboa: Revista da faculdade de ciências sociais e humanas, n. ${ }^{\circ} 18$, edições colibri, 2006. p. 59-82

IBGE. Instituto de Geografia e Estatística. Censo Demográfico 2010: educação. Disponível em: http://www.ibge.gov.br/home/estatistica/populacao/censo2010/educacao. Vários acessos.

KERCKHOVE, D. de. A pele da cultura: Uma Investigação Sobre a Nova Realidade Eletronica. Tradução Luís Soares e Catarina Carvalho. Lisboa: Relógio d'Água Editores, 1997.

LÉVY, P. A inteligência Coletiva: por uma antropologia do ciberespaço. São Paulo: Edições Loyola, 1998.

As tecnologias da inteligência: $O$ futuro do pensamento na era da informática. Rio de Janeiro: Editora 34, 1993.

LEMOS, A. \& JOSGRILBERG, F. (Org). Comunicação e mobilidade: aspectos socioculturais das tecnologias móveis de comunicação no Brasil. (Org.). - Salvador: EDUFBA. 2009. 156p.

Cibercultura e Mobilidade. A Era da Conexão1. Intercom - Sociedade Brasileira de Estudos Interdisciplinares da Comunicação. XXVIII Congresso Brasileiro de Ciências da Comunicação - UERJ. Anais, 2005.

Sulina, 2002.

Cibercultura. Tecnologia e Vida Social na Cultura Contemporânea. Porto Alegre:

LEMOS, A. \& CUNHA, P. (Org.). Cibercultura. Alguns pontos para entender nossa época.

Olhares sobre a Cibercultura. Sulina, Porto Alegre: 2003; pp. 11-23.

MARTINS, J. de S. 1938 - Exclusão social e a nova desigualdade (Coleção temas de atualidade). São Paulo: Paulus, 1997.

MASSEY, D. B. Pelo espaço: Uma nova política da espacialidade. Tradução Hilda Pareto Maciel, Rogério Hasbaert. Rio de Janeiro: Bertrand Brasil, 2009. 314p.

MATOS, E. da S. R. Espacialidades em rede: população, urbanização e migração no Brasil contemporâneo. / Ralfo Edmundo da Silva Matos (organizador); [autores]; Rodrigo Nunes; Cássio Francisco de Lima... [et al]. - [Editor: Fernando Pedro da Silva] - Belo Horizonte: C/Arte, 2005. 264p.

PRETTO, N. e PINTO, C. da C. Tecnologias e novas educações. Rio de Janeiro: Revista Brasileira de Educação v. 11 n. 31 jan./abr. 2006. https://doi.org/10.1590/S1413-24782006000100003

Plano Desenvolvimento Institucional-PDI (2016-2020). Universidade Federal do Tocantins. Palmas: Conselho Universitário (CONSUNI); UFT, 2016. 
Projeto Pedagógico do Curso de Geografia- PPC. Resolução do Conselho de Ensino, Pesquisa e Extensão (Consepe) N.ํ 46/2009. Universidade Federal do Tocantins. Araguaína; Dezembro de 2009.

QUEIROZ, A. M. D., - Análise geográfica sobre o espaço virtual de ensino a partir das experiências na educação a distância da Universidade aberta do Brasil no norte de Minas Gerais / Antônia Márcia Duarte Queiroz - 2016. Tese (doutorado)- Universidade Federal de Uberlândia, programa de pósgraduação em geografia.

I Seminário online do Curso de Geografia da UFT/Araguaína". Atividades acadêmicas do Câmpus de Araguaína - 2020/1. Universidade Federal do Tocantins, de 08/06/2020 a 09/06/2020.

VALENTE, J. A. Blended learning e as mudanças no ensino superior: a proposta da sala de aula invertida. Educar em Revista, Curitiba, Brasil, Edição Especial n. 4/2014, p. 79-97. Editora UFPR. https://doi.org/10.1590/0104-4060.38645

Recebido em: 11/06/2020

Aceito para publicação em: 21/12/2020 